\title{
TITLE:
}

\section{Learning from the past: Trends and dynamics in livelihoods of Bolivian forest communities}

\section{$\operatorname{AUTHOR}(S)$ :}

Zenteno, Mario; de Jong, Wil; Boot, Rene; Zuidema, Pieter A.

\section{CITATION:}

Zenteno, Mario ...[et al]. Learning from the past: Trends and dynamics in livelihoods of Bolivian forest communities. Environmental Science \& Policy 2014, 40: 36-48

\section{ISSUE DATE:}

2014-06

URL:

http://hdl.handle.net/2433/188738

\section{RIGHT:}

(C) 2014 Elsevier Ltd.; This is not the published version. Please cite only the published version.; この論文は出版社版でありません。引用の際に は出版社版をご確認ご利用ください。 


\title{
Learning from the past: Trends and dynamics in livelihoods of Bolivian forest communities
}

Mario Zenteno ${ }^{1}$, Wil de Jong ${ }^{2}$, Rene Boot ${ }^{1,3}$ and Pieter A. Zuidema ${ }^{4}$

1. Tropenbos International

2. Center for Integrated Area Studies, Kyoto University

3. Utrecht University

4. Forest Ecology and Forest Management Group, Wageningen University and Research Center

\begin{abstract}
We use social ecological systems theory (SES) to analyse change in forest communities in the northern Bolivian Amazon. SES characterises interdependent dynamics of social and ecological systems and we hypothesized it to be a useful frame to grasp dynamics of forest communities affected by changes in forest policies, regulations and institutions, as well as economic demands and conservation objectives. We analysed the long-term historical changes since the region became incorporated in the global tropical forest product value chain since the late $19^{\text {th }}$ century and quantitatively analysed changes in 85 forest communities between 1997 and 2009. We collected information on 16 variables related to demographic, productive, and socio-economic characteristics. Results show that forest communities have experienced major changes and have adapted to these changes. Social thresholds, a key concept in SES, are consistent with multiple social economic forces experienced by forest communities. Detrimental feed-back effects of SES can be confronted when innovative exploration mechanisms, such as new productive chains are developed, or the agro-extractive cycles of current productive system are expanded. Competition among households, population growth and more profitable economic opportunities may threaten benign forms of forest products extraction that have persisted through various cycles of internal and external changes.
\end{abstract}

Keywords: Community forestry, Bolivian Amazon, Brazil nuts, Social-ecological systems, Technological and social thresholds 


\section{Introduction}

Political, economic and social forces affect the livelihoods and resource use of forest dependent communities (Mwangi and Ostrom, 2009; Walker, 2005: 80). Such events, occurring at macro and meso levels, may create political, social and economic incentives that promote or supress the sustainability of resource use systems and may induce changes in societies (e.g. Assies, 1997: 36; Cronkleton and Pacheco, 2010). There is a necessity to identify the drivers that influence how communities manage and exploit resources (e.g. de Jong, et al. 2010; Perz and Almeyda, 2010). However, where such drivers operate, they usually do not operate simultaneously, their impacts are not homogenous, and some of them are cyclical while others are not (Agrawal et al., 2008: 1460; Andersson and Ostrom, 2008; Moore, 2011). Therefore, it is relevant to assess the influences of such drivers on community development, in order to understand the capabilities of communities to manage natural resources sustainably.

Social-ecological systems theory (SES) is an analytical frame to understand interdependent dynamics of social systems (people and their social and economic attributes) and ecological systems (ecology and natural resource exploitation) (Berkes et al., 2003; Holling, 2001). SES, therefore, is useful to analyse changes of forest dependent communities. An important concept in SES is resilience, defined as a system's capacity to reorganize while sustaining functional characteristics, which is similar to adaptation (Walker et al., 2006). Reorganization implies changing productive and organizational structures to absorb external pressures and avoid trespassing any critical thresholds that may lead to undesired irreversible changes (i.e. over-exploitation of natural resources to the point that they collapse) (Renaud et al., 2010). A next important concept is technological or social thresholds. These are tipping points when acceptable conditions turn into unacceptable conditions (Christensen and Krogman, 2012) and thus are quite relevant to natural resource dependent communities.

Understanding the responsiveness of communities in a given SES is relevant, because changes may bring benefits and opportunities but also incur costs (Janssen and Scheffer, 2004; Liebowitz and Margolis, 2005: 985). Communities with high responsiveness to changes suggest availability of well-developed capacities or networks (horizontal or vertical), and this is consistent with feedback effects in SES (Christensen and Krogman, 2012). When social thresholds are reached investments are required in the forms of explorations of innovative resource use (Chabay et al., 2011; Duit and Galaz, 2008; Lam, 2000; March, 
1991). We hypothesize that social adaptability in communities depends on the nature of resources use patterns and the evolution of local social economic relations.

Responses to changes at household level may enrich the understanding of resource use patterns (Assies, 2002). Assies (1997) proposed the concept of the agro-extractive cycle to characterize forest dependence of the northern Bolivian natural resource economy. He argued that extraction-based livelihoods in the region are sustainable, but they are strongly influenced by volatile markets, exploitative labour relations, and excessive exploitation of natural resources (Assies, 1997). In such conditions, changing access to markets, demographics, social differentiation and accumulation, in addition to impacts on natural resources may drive changes of resource use (Assies, 2002; Frankenberger et al., 2003; Homma, 1992, 1994). As households enter into a market economy they may alter the nature of agro-extractive cycles (Delacote, 2007; Godoy et al,. 2007; Labarta et al., 2008; Sierra et al., 1999; Takasaki et al., 2001; Takasaki et al., 2011). Therefore, micro level responses to changes may also explain how livelihoods develop new paths of forest use.

There are various interpretations of how forest-incomes may prevent extractive economies to change. One is that rural dwellers use forest-incomes to buffer risks of stable food production and other incomes (Delacote, 2007; Pattanayak and Sills, 2001). Another is that specialization on certain natural resources is conditioned by the configuration of the production factors labour, land and capital. If production factors are abundant or markets are risky, the composition of productive activities are likely to remain stable (Sierra et al., 1999; Takasaki et al., 2011). Such micro economic analyses, however, are based on a household model, but spatio- temporal variations are not taken into account. Spatio-temporal variations are relevant as they better accommodate the natural resource dimension of SES, and may better anticipate diverging tipping points which may be similar to SES thresholds. We use those concepts to describe and analyse cycles and trends of natural resource use in the northern Bolivian Amazon.

Using the SES theory as an analytical frame, this study analyses historical changes since the early $20^{\text {th }}$ century and more detailed changes between 1997 and 2009 among forest communities in the northern Bolivian Amazon region. Important changes over the last decade are devolution of rights to communities, the implementation of a new regulatory forest management regime, a steady increase in the international market price of Brazil nuts, the main commodity produced in the region, and improved road access to communities (Cano, 2012; de Jong, 2004; Ruiz, 2005). The impacts of these major changes and their interactions, on communal resource management and related collective action are rather unclear (Barham 
and Coomes, 1996; Caldas et al., 2007; Stoian, 2000). No detailed analysis of changing the adaptive capacity of communities in the region has yet been performed. The questions to be answered then are: (1) What changes have shaped forest dependent communities in northern Bolivia? (2) Which factors have determined trends of resource use in these communities? (3) To what extent are communities in northern Bolivia able to adapt to changes? (4) What type of investments on resource use do communities make to adapt to their changing environments? (5) What is the impact of changes and consequent social and economic adaptations to the ecological system?

\section{Materials and methods}

We reviewed the history of the northern Bolivian Amazon region, based on published accounts. In section three we present a review of this historical transformation, highlighting economic, demographic and political changes. We conducted an initial qualitative survey in September 2007 to March 2008 in ten communities, holding in-depth interviews with local leaders and community members to obtain information on the history and changes related to forest use, forest condition change, agricultural production and demography in communities.

We conducted quantitative surveys in 85 communities as part of a wider study on livelihoods among the region's forest communities (Zenteno, 2013; Zenteno et al., 2013). To evaluate the changes over the last 12 years, we combined data on 163 settlements from a study carried out by Stoian and Henkemans in 1997 (Stoian, 2000; Stoian and Henkemans, 2000; Henkemans, 2001) with our own data from 2009 (Zenteno, 2013; Zenteno et al., 2013). The Stoian and Henkemans survey focused on communities located at the main rivers, and less so on communities located in the eastern and northern parts of the region. As a result 30 communities matched our own survey. We obtained the necessary information for the remaining 55 communities from multiple government sources to complete the data set for 1997 (Table 1), to allow for a full comparison of all the 85 communities.

We use data for 16 variables related to demography, production and community organization in our analysis. Of 14 of these 16 variables it was possible to obtain data for 1997 and 2009. Of the 16 variables 13 were continuous and three variables were binary. The 85 communities for which we compare the changes between 1997 and 2009 are well distributed geographically and represent $32 \%$ of the officially identified communities in the region (Fig 1). The sample includes communities that were accessible by roads or rivers, with 
or without officially recognized communal territory, and communities that varied in number of inhabitants (Zenteno, 2013).

\section{FIGURE 1}

We calculated for each community, the magnitude of change in each of the variables between 1997 and 2009. We used multivariate analysis tools to analyse all variables of 81 communities to derive general patterns of change (ter Braak and Verdonschot, 1995; Okland, 1996), excluding four communities from the analysis as they turned out to be outliers in the preliminary data screening. We used paired t-tests to assess whether changes in variables for which we had data for both 1997 and 2009, were significant. We also applied correspondence analysis (CA) to aggregate 10 variables used as measures of change into a few summarizing variables (canonical axes) (Greenacre and Pardo, 2006). Binary variables (2, 15 and 16, Table 1) only entered into the analysis, after having completed CA. Variable 6 was excluded from $\mathrm{CA}$, because the large proportion of zeroes and variables 13 and 14 because of the lack of data for 1997.

\section{Historical transformations of the northern Bolivian Amazon}

\subsection{Economic transformations}

The northern Bolivian's economy developed over more than a century, beginning with the exploitation of quinine (Cinchona spp), followed by rubber (Hevea braziliensis) and Brazil nuts (Bertholletia excelsa). During the mid-1990s for a brief time palm heart (Euterpe spp.) was exploited, and since about the same time logging in the region intensified and continues until today (Pacheco, 2012; Stoian, 2000). Until the late 1990s northern Bolivia was more integrated with the Brazilian Amazonia economy than with the rest of Bolivia (Assies, 1997). After improved access to national markets, commodities such as rice, maize, horticultural products and gasoline and diesel nowadays come from the Andean regions of Bolivia, while before 2003 these were mainly imported from Brazil (Hinojosa, 2005). Brazil nuts are now also exported through pacific ports (IBCE, 2008), and not via Brazil anymore as happened until the early 1990s (Bojanic, 2001). Timber from the region is sold domestically to exporters located in the bigger cities of Bolivia (de Jong et al., 2013). 
The region's agro-extractive cycle (Assies, 1997) combined rubber tapping and Brazil nut extraction largely as consecutive activities during the year. Forest workers tapped rubber during the dry season and collected Brazil nuts in the period between November and March. In between rural residents practiced agriculture. This agro-extractive productive cycle was stable and largely sustainable (Assies, 1997). Rubber production continued until the late 1980s (Stoian, 2000), supported by subsidies from the State of Acre, where Bolivian rubber entrepreneurs sold their produce. Since when rubber production declined Brazil nut collection and agriculture contribute almost $60 \%$ to household economies and 30\% of the region's income (Ruiz, 2005).

Agricultural production is mostly for household consumption, relying on family manual labour and simple tools and little other inputs. Near the regional urban centres a gradual shift towards cattle production is taking place, made possible by the availability of capital and low prices for land (SENASAG, 2010).

When rubber prices fell in 1986, because Brazil stopped its subsidies, it caused a stagnation of production and a debt crisis especially of medium sized enterprises also among Bolivian producers (Bojanic, 2001). In northern Bolivia, the rural population depended on informal loans (locally called habilito), when collecting rubber and Brazil nuts and the debts were paid back with produce (Cano, 2012), often resulting in debt-peonage. When Brazil nuts became the only commercially traded forest product, rural dwellers had to rely on agriculture for almost eight months of the year (April to November; Assies, 1997; Stoian, 2000; Cespedes, 2005).

The Brazil nut production chain expanded significantly since the early 1990s, when regional entrepreneurs invested in shelling facilities to manufacture a product directly sold to food product manufacturers. As a result entrepreneurs also began to control the financial flows, including the trading of the end product in international markets (Bojanic, 2001).

Since the early 1990s, the regional road network in northern Bolivia has improved significantly. In the late 1980s and early 1990s important road links were completed between major towns. By the late 1990s, many secondary roads were completed and almost $60 \%$ of all communities in the region are now connected by road. The secondary roads were mainly constructed to facilitate timber exploitation. The improved access decreased the dependence among community members on merchants who previously travelled to communities and traded commodities as advanced payments, or informal loans for forest products to be collected later. The role of such itinerant merchants has declined, suggesting new forms of 
Brazil nut commercialization and a changing, but not yet declining role of habilito (Pacheco et al., 2009; Cano, 2012).

The barraca-based forestry production (Cespedes, 2005), resembling a semi-feudal arrangement of property and social relations (Aramayo, 2004), continued in northern Bolivia until the late1990s. It has now largely disappeared because of the sweeping land reforms that began since the mid-1990s (Ruiz, 2005). The transition to rural communities began around the first agrarian reform in 1953, which coincided with a severe crisis of the barraca based forest product exploitation (Bojanic, 2001; Stoian, 2000). The barraca system was again put under pressure since the 1986 drop of the rubber prices. The latter meant that the resident labour could not be employed year round anymore, and many settled in communities where they started a livelihood independent of the barraca (Ruiz, 2005), or they migrated to the region's three main urban centres Cobija, Riberalta and Guayaramerin (Stoian and Henkemans, 2000; Henkemans, 2001; Llanque, 2006). The local elite progressively began to invest in cattle ranching, and logging in the newly accessible forest areas (Bojanic, 2001).

The legal reforms in land tenure and access to forest resources in the 1990s have led to the formal recognition of rural communities in the northern Bolivian Amazon (Ruiz, 2005). These developments also created more opportunities for independent Brazil nut extraction by rural communities. Household production, however, is often limited due to a shortage of labour. There is a tight relation between the number of persons per household and the size of the forest lands that families exploit (Cronkleton and Albornoz, 2009). Where people have larger plots than can be harvested with family labourers, households will ask the help of relatives or even engage itinerant Brazil nut collectors. Families, therefore, can increase Brazil nut production, but this depends on Brazil nut prices, labour costs, but also on the acquiescence of other members of their resident community (Cano et al., 2014).

The changes of the last twelve years unfolded during a steady increase of Brazil nut prices. The 2009 price obtained by communities was $71 \%$ higher than the 1997 price, even though the international FOB prices were only $33 \%$ more, and prices received by communities represented about 30 to $40 \%$ of the export price of Brazil nut (Stoian, 2000; INE, 2011). The 1997 - 2009 period coincided with more stable prices for all other products in Bolivia, and a relatively stable exchange rate. During that time staple products (e.g. sugar and rice) increased only between 20 to $30 \%$ (INE, 2011).

\subsection{Political transformations}


In 1994 Bolivia started a process of profound political reforms including administrative decentralization to local municipalities, land reforms and forestry reforms that had great influence on the northern Bolivia region (Ruiz, 2005). For instance, the criteria to distribute public resources under the decentralization reforms on a per capita basis and the option of public influence of municipal decision making was a strong incentive for human settlements in the region to register as formally recognized communities, something that had not yet happened before (Ruiz, 2005). Until 1996, before the new land reform took place, only 13 communities were formally recognized in the region (Cespedes, 2005). Since then the population centres of barracas have experienced an accelerated transition to officially recognized communities, with schools and a communal government as required by law (de Jong et al., 2006). While these formal administrative changes took place, the previous barraca owners, or their relatives, widely co-opted political powers and commonly continued to exercise control over the resident population of the new legal communities (Cespedes, 2005; Cano et al. 2014; Cano, 2012).

When conditions for community recognition existed since the mid-1990s, there was disagreement about the size of forest lands that should be allocated to communities, and how forest exploitation by community members could be guaranteed. This led to a discussion on the need to define land and forest areas per household within the newly established communities (Aramayo, 2004). On the other hand, it was proposed that barracas continued to operate as non-timber forest products concessions. These issues resulted in confrontations between indigenous and peasant social movements and the national government during 1999 and 2000 (Ruiz, 2005). The final outcome of these struggles was that each household should be allocated a minimum area of 500 ha, but as part of a single, collectively held communal property (INRA, 2011). At present, almost $40 \%$ of the region's forest areas are in the hands of forest communities (INRA, 2011), but internal arrangements of the de jure collective ownership is showing considerable variation in the region. Cano et al. (2014) observed three typical arrangements: one that emphasized free access of commonly held forest resources, but respecting the principle of equality; respect for pre-reform unequal access rights among village members mostly sanctioned by powerful families in communities; and a reinforcement of de facto private rights that already had established themselves when communities engaged strongly with regional markets previous the reforms.

During the second half of the 1990s, a new Forest Law and Land Reform Law were implemented (Contreras-Hermosilla and Vargas, 2002; de Jong, 2004; Ruiz, 2005). The two laws had a profound impact on ownership over forests and communities for the first time 
could organize themselves as small and medium sized legal forestry entrepreneurs. Communities equally have to follow forestry regulations and implement forest management plans (FMP). In response to these requirements, private enterprises have negotiated with communities to provide initial capital for implementing FMP (Ruiz, 2005; Benneker, 2008), or local NGOs and international conservation and development programs assisted communities to meet the administrative requirements (Pacheco and Cronkleton, 2005; Benneker et al., 2005; Benneker, 2008).

\subsection{Environmental transformations}

The northern Bolivian Amazon region is an atypical SES among tropical forest regions for its relatively minor environmental transformation, especially compared to other tropical forest regions that experienced forest frontier transformation processes. For instance, the department of Pando with a total area of 6.4 million, which constitutes the largest part of the Bolivia's northern Bolivian Amazon, experienced 88,222 ha total deforestation between 1978 and 2001, or an average of 3,836 ha/ year (Reyes et al., 2011). With figures from CLASlite ${ }^{1}$, which gives accumulated deforestation between 1985 and 2011 of 328.577 ha, we calculate the deforestation between 2001 and 2011 to be 240,355 ha. While this is a drastic increase compared to the previous years (but see also Reyes et al., 2012 for differences in estimates), the cumulative deforestation is still only $5.8 \%$ of the department's forest area. The limited deforestation is a result of the region's isolation, as it did not have any all-weather road connection until the early 1990s, and because of the region's forestry dominated economy. Residents when they were still part of the regions barracas labor force were forbidden to practice agriculture (Stoian, 2000), and except for settlements near the regional towns, commercial agriculture, including cattle, remains minimal.

Future environmental transformation will be driven by various opposing forces that are present today. The region important shift in ownership of forest lands is an important safeguard against cattle or agro-industrial frontier dynamics reported from, for instance, neighbouring Brazil. The northern Bolivia communities are now owners of a large part of the region's forests and forestry remains a principal and preferred livelihood option (Cano et al., 2014; Zenteno et al., 2013). Before the 1990s timber extraction was not a major factor in the region, but this has changed since roads improved, and the timber sector has become a major

\footnotetext{
${ }^{1}$ http://claslite.carnegiescience.edu/en/success-stories/herencia-bolivia-deforestation-mapping
} 
economic activity. Forest extraction has mixed impacts on various forest attributes. Brazil nut extraction has no foreseeable impact on the tree's natural population in the region (Zuidema and Boot, 2002). Timber extraction is still limited to only a few species, with as yet minor impact on the forest's species richness (Putz et al., 2012), especially at the low logging intensity practiced in the region, and species richness recovers rapidly when secondary forest develop on former agricultural fields (Peña-Claros 2003). During the 1990s palm heart extraction (Stoian, 2000) Euterpe spp. natural populations, were devastated. Extractive activities, however, do have an important impact on the regions forest fauna as especially seasonal Brazil nut collectors and inhabitants of forest communities spend important periods in the forest and hunt intensively (Zenteno et al., 2013). The region is, furthermore, within the influence sphere of the northern part of the inter-oceanic corridor, the road that connects the Atlantic coast with the Pacific coast. In addition, the existing roads connecting the region to the rest of the country are also being improved or planned to be improved in the near future (Reyes et al. 2011). Not the least, Brazil is now constructing a hydroelectric dam in the Madeira river, which travels through Bolivia's northern Amazon. There will be direct impacts on flooding regimes and river fauna, but also important indirect impacts similar to those caused by the inter-oceanic corridor.

While the northern Bolivian SES is highly linked to the particular ecology of the region's forest, forest dynamics did not play a major role in the social and economic changes that we analyse in this paper. For that reason, no environmental variables were included the analysis in Section 4, of changes between 1997 and 2009.

\section{A quantitative analysis of recent changes in forest communities}

The values of 16 variables and changes of 14 variables between 1997 and 2009 are shown in Table 1 and briefly described below. The magnitude of changes was large for quite a number of variables: various variables doubled while others decreased by $50 \%$. Changes in 13 out of 14 variables were found to be significant (Table 1).

\section{TABLE 1}

Populations in the 85 communities increased by an average $64 \%$ during this period, representing an annual growth rate of $4.3 \%$, which corresponds to the average population growth in the region (INE, 2010). Due to construction of secondary roads over the last 12 
years, the access to communities has greatly improved. In 1997, the average travelling time to urban centres for the 85 communities was seven hours, but this has now been reduced to four hours. Also, the proportion of communities that trade Brazil nuts mainly by road has doubled since 1997. Today, $75 \%$ of the communities are able to trade Brazil nuts by roads, while in 1997 over $60 \%$ of the communities depended entirely on rivers to sell Brazil nuts. Parallel to this change in access, the average price paid to communities for a box of Brazil nuts also doubled between 1997 and 2009. This increase is due to the abovementioned increase in Brazil nut prices at the international market, but probably also in part to the improved access to the communities, leading to more competition among Brazil nut processing plants for their raw material.

We observed strong increases in total Brazil nut production per community. In 2009 communities sold $71 \%$ more Brazil nuts compared to 1997 . The area of pasture for cattle ranching per community also increased dramatically by 50\%; from 167 ha in 1997 to 256 ha in 2009. Although this is a significant increase, the area under pasture per community remains on average less than $10 \%$ of the total community area. Both changes in productive parameters may be related to increased population size as well as to increased accessibility of communities. In contrast to the positive changes in productivity at community-level, the productive parameters per household decreased between 1997 and 2009. Brazil nut production per household declined by $20 \%$, while the area of agricultural land per household declined by $50 \%$. The proportion of households in communities that receive habilito (informal loans) decreased from $92 \%$ in 1997 to $56 \%$ in 2009, a remarkable change considering how strongly culturally embedded habilito is in forest product production in the region (Bojanic, 2001; Cano, 2012).

Heterogeneity of community members is relevant to understand social and economic differentiation, and adaptation to institutional changes (Poteete and Ostrom, 2004; Agrawal et al., 2008). Social and economic heterogeneity may modify over time, regarding changes among community relations and with economic differentiation or forest uses (Adhikari and Lovett, 2006). We constructed instrumental indices of fractionalization, to assess heterogeneity trends of two group classification variables. Local definitions of new and old community members were used to capture social differences, and the proportions of household income sources was used to capture economic heterogeneity (Baland and Platteu, 1999; Takasaki et al., 2011). Social and economic heterogeneity indices suggest the following trends. The social index has decreased, indicating that local communities have now populations pertaining to less variable social group types (e.g. new members vs. old 
members). On the other hand, the economic characteristics index, measured as the members pertaining to different livelihood types (hunters, Brazil nut extractivist, agriculture, cattle ranching, services and timber, see Zenteno et al., 2013 for a detailed characterization of northern Bolivian livelihood types) suggest that income generation activities have diversified. Thus communities have become more homogeneous in composition over time, but its members pursue more diverse economic opportunities.

\subsection{Associations among changes}

Table 2 presents bivariate correlations among changes of the 11 continuous variables with data for 1997 and 2009. None of the correlations are strong, but they do provide new insights that explain observed changes. A positive correlation between changes in two variables indicates that communities in which one variable showed a positive change also showed positive change in the other variable; a negative correlation indicates the opposite, or a strong positive change in one variable concurred with minimal change or negative change in the other variable.

\section{TABLE 2}

We found a positive correlation of change in total Brazil nut production at community level with the change in population size increase of the community. This means that communities that harvested more Brazil nuts over time also tended to increase more in population size. This is quite logical as total harvest of Brazil nuts is very much linked to labour availability. But in communities where populations grew more rapidly, the amount of Brazil nuts collected per household decreased more than in communities which lower change in population growth rates, suggesting competition among households for the limited amounts of Brazil nuts. In fact, we know that such competition exists, resulting in theft of Brazil nuts (Duchelle et al., 2011) and conflicts among community members (Cano, 2012). Similarly, competition may exist between households for agricultural land as communities that increased population, showed a lower increase or a decrease of yearly per household farmed land.

Communities in which the proportion of the population that finished primary school grew, also grew more in population. These communities equally showed an increase in the social homogeneity index, which is unexpected since communities with larger populations 
can be expected to be socially more heterogeneous. The strong reduction in the incidence of habilito was related to changes in access. We found a negative correlation between the proportion of habilito and the changes in access to the main towns (measured in hours of travel to towns). Thus, in those communities where travelling time to main towns declined strongly, the percentage of the population receiving habilito did not decline as strongly as in those communities for which travelling time remained similar. This is again somewhat unexpected as it would be logical that habilito declined more in communities that were remote in 1997 than they are today. We hypothesize that this is the case because active local networks to sell Brazil nuts and purchase products were maintained over time despite changes in accessibility.

\subsection{Multivariate analysis of changes}

We used correspondence analysis (CA) to describe the composition of changes (i.e. 10 measurements of trends into fewer dimensions). Fig 2 shows the results of the CA analysis. In both panels in this figure, each dot represents one community and distance among dots refers the degree of dissimilarity among communities with respect to the changes that they experienced. The graphs show grouping of the 81 analysed communities and no separate clusters of communities can be observed. This implies that there are gradual differences between communities in the way they have changed.

\section{FIGURE 2}

\section{TABLE 3}

The two axes of the figures are the first two canonical axes that explain $45.1 \%$ of the total variation in the changes of 10 variables that could be used as measures of change. To interpret what these two canonical axes represent, one can correlate the values of communities along these axes to the values of change in each of the 10 variables (Fig 2a) and to the values of these axes to variables in 1997 and 2001 (Fig 2b). Table 3 reports the coefficients for these correlations.

The two canonical axes correlated with variables of change, with varying strength (Fig $2 \mathrm{~b}$ ). Axis 1 can be considered as the axis of household productivity and competition. The more negative values on this axis indicate households with slightly increasing or stable levels of harvested amount of Brazil nuts. Positive values along this axis indicate communities with 
stronger population growth and therefore more competition among households, resulting in a larger reduction of the amount of Brazil nuts harvested per household.

The second canonical axis (Axis 2) can be considered to be the axis of intensification of forest vs. non-forest activities (Fig 2a). Positive values along this axis are correlated with a larger increase in Brazil nut harvesting at community level, while negative values are related to a larger increase in agricultural areas, cattle ranching and a higher proportion of forest loss. So, communities with positive values along this axis are the ones that had a larger increase in the amount of Brazil nuts harvested, while those with negative values increased more agricultural activities, resulting in forest loss.

We also correlated the canonical axes with the conditions of 1997 and 2001 (Fig 2b).

Interestingly, we found that the household productivity and competition axis (Axis 1) showed significant positive correlation with Brazil nut harvest per household in 1997, suggesting that communities with households that sold large amounts of Brazil nuts in 1997 were the ones that grew more in population and decreased in household productivity.

Correlations with the Axis 2, the axis of intensification of forest vs. non-forest activities, shows that communities that had larger populations and higher production of Brazil nut per community in 1997, experienced increments of non-forest activities changes. So, communities that had a quite intensive forest use and were relatively large in 1997 have shown a certain degree of agricultural intensification. These are also the communities that were located closest to the main towns in 1997.

\section{Discussion}

We presented an overview of trends among forest communities in the northern Bolivian Amazon. Our analyses show that forest communities have experienced tremendous changes in the political, economic environment, land tenure and accessibility realms. This has as yet had minor impact on the region's forest cove but that could possibly change in the future. Future forest cover changes, cause largely by forces from outside the region as explained in Section 3, will also largely modify the trends signalled here. More relevant, however, is an extensive implementation of entitlement process resulting in a situation in which almost $40 \%$ of forest area is in hands of communities. At social - institutional level, the barraca system has collapsed and the majority of forests settlements in the region (almost $75 \%$ ) are now legally recognized independent communities. Demographically, forest communities have also experienced strong changes, with an increase of average population (64\% in 12 years). 
Currently, communities represent almost $15 \%$ of the regional population and above $60 \%$ of rural population. These new conditions have promoted a new social organization that represents implicitly new conditions for local livelihoods. The extent of the development of forest communities in the region still can be considered new, since the process of entitlement has finished only recently.

Notwithstanding, the economic base of the northern Bolivian Amazon has remained close to its extractivist roots and still depends strongly on forest communities and temporary workers residing in regional towns. In fact, the steady increasing of Brazil nut prices resulted in a renewal on the economic life of the traditional extractive system. Increasing harvesting levels of Brazil nut has not yet reached threshold levels, largely because of the resilience of Brazil nut populations (Zuidema and Boot, 2002). However, new economic options for local communities are available, permitting an increased diversification, like exploitation of timber, semi-commercial agriculture and cattle ranching in areas that were already cleared, and communities becoming more easily linked to regional towns.

Which are the factors that determine the cycles and trends of resource use of the northern Bolivian social ecological system? A scenario of the changes in forest use is that local populations are still largely dependent on local subsistence production and on commercial uses of forests. In this situation, intensification of forest use and increased populations are present where advantageous prices permit more extraction of resources (a steady increase of a particular resource, with high commercial value). However, these populations only have temporal presence in communities as they migrate seasonally from the regional towns to join Brazil hut harvesting (Zenteno et al., 2013). In remote communities with poor and costly access, population densities may remain low. On the other hand, the improvements of access may promote more dynamism of local changes, resulting in more stable local populations. Thus, because local extractive products are only seasonal, this may permit the need of land use changes. Unless forest product extraction reaches a productivity limit or if new economic activities result in high opportunity costs for extraction, extraction will remain constant. A third factor, an accelerated advance of forest destructive activities and a subsequent demise of the Brazil nut economy, is as yet not a major threat in the particular region of the tropical Amazon basin, but this may be a factor of more importance in the future.

In a micro economic interpretation, these assertions are consistent with the model suggested by Homma $(1992 ; 1994)$ on extractive economies. The model holds that extraction rises to a point of stabilization, where specialization to narrow sources of incomes may 
promote changes of the resource base. However, this should be detailed along a spatial continuum. Sierra (2001) indicated that this process may not be as fast as the theoretical model is proposing, because abundant labour and land are factors that have low opportunity costs in a first stage of integration with a commercial economy. A second set of empirical studies by Pattanayak and Sills (2002) and Delacote (2007) suggests that forest products extraction is influenced by seasonal risks of agricultural production. In both cases, the conditions are dependent on access and other opportunities of resource extraction and production.

Our results suggest that Brazil nut extraction may not be consistent with an income assurance function to complement agriculture, because labour may adjust temporally with the relative abundance of resources, a situation that is likely to persist in the foreseeable future. A forest products is the basis of a specialized cash income economy, in which it remains a stable component or its role increases when market opportunities are stable or demand increases. In such case, local populations maintain their productive structure and balance the risks of extraction with sustaining social and economic relations (for instance through a continued use of habilito; Cano, 2012). Only when local levels of extractive production per household drop beyond a tipping point, the trend will become to switch to agriculture, timber extraction or other opportunities. Therefore, our results are consistent with Homma's model as a macro trend. However, locally (or spatially) there is a continuum of differences among households and communities. Consequently, changing patterns of economic dependence and the cycles of extraction remain important in some communities but less so in others.

So, to what extent are communities, like those in northern Bolivia, able to adapt when SES changes occur? Our results indicate that communities have responded significantly to the economic, social and political changes, indicating a high capacity to adapt to such changes. In some cases, such responses are a direct effect of changing prices and accessibility to markets. For instance, the increase in the Brazil nut price paid to communities is responsible for the increase of total Brazil nut extraction per community. Also, the improved accessibility to communities and already cleared areas are responsible for the $50 \%$ increase in cattle ranching area per community. Those structural elements can consistently be interpreted as a feed-back effect for the SES (Christensen and Krogman, 2012), because they promote divergent poles of community behaviour.

The response of communities is the result of clear adaptation processes, when the institutional setting favours local organization. For instance, $30 \%$ of the forest communities in the region have now implemented formal forest management plans (FMP) which are 
required to extract timber from community-managed forests (Zenteno, 2013). The implementation of such management plans requires the establishment of forest committees within communities, which depend strongly on participatory processes. Cano (2012) showed that the shifts in land tenure and forest regulation have changed the organization and power relations within communities. In those communities, local governance changed depending on forest economic values and involvement of local organizations.

The apparent adaptive responses that we have observed need to be evaluated over time. Our multivariate analysis showed that communities that had larger populations and had higher total Brazil nut yields in 1997 developed towards more agricultural and cattle-ranching communities, in which a larger share of previous forest area is now used for crop fields and pasture areas. These were also the communities that were located closer to the main towns in 1997. On the other hand, the more remote and smaller communities in 1997 increased more in population size and in the amount of Brazil nut harvested. These results confirm that population dynamics of communities have high correlations with economic opportunities and sustaining an extractive economy (Stoian, 2000). This underlines the capacity of communities to adapt to changes, by balancing extractive activities with subsistence agriculture, cattle ranching and other opportunities. This also suggests that while communities adapt to changes, their capacity of balancing or maintaining an extractive economy is less certain.

The exploration of new capabilities to manage forest resources is relevant to prevent conditions of reaching thresholds of the SES. Thresholds here may need to be interpreted as a drastic change of a variable to a new steady condition (desired or undesired). Results presented demonstrate some relevant conditions of such thresholds, specially related to the extent of economic and ecologic thresholds. Based on our results, what kind of economic or ecological thresholds are to be expected among northern Bolivian forest communities? The extraction of many non-timber forest products has shown typical strong rises and steep falls (Homma, 1992; 1994). Such boom and bust cycles are driven by increased demand (the boom phase) followed by collapsing prices (e.g. due to the availability of cheaper alternatives from plantations or synthetic production) or resource depletion, both leading to bust. There seems to be evidence for a boom in Brazil nut extraction and in the communities' economies.

Our results on temporal changes in productivity can provide some information to evaluate thresholds. The multivariate analysis shows that those communities with high levels of total Brazil nut extraction in 1997 have shown a shift towards more agricultural use (in 2009). This suggests that the intensity of extraction only increased modestly. On the other hand, those communities with a low total annual Brazil nut extraction have shown an increase 
in Brazil nut harvest over time. Even with an increase in harvest intensity, Brazil nut production will likely not decline, because ecological sustainability analyses of Brazil nut extraction have shown that stands of Brazil nut trees will continue to produce high amounts of Brazil nuts for the coming 50-100 years, even when harvesting is very intense (Zuidema and Boot, 2002). In all, the risk of depletion of Brazil nut as a natural resource is unlikely to be caused by overharvesting of Brazil nuts but rather by forest loss, even in the cases when Brazil nut trees are left in agricultural areas or pastures.

Habilito, the customary and informal loan system of the region, appears as a surprising factor that functionally maintains the local extractive structures. The results of the multivariate analysis indicate that at present fewer households use this largely network-based finance mechanism. It is now spread in places where high competition of Brazil nut exists, but not necessarily where increased population or increased extracted volumes are located. This suggests that reliance of household on habilito relates to different household strategies. These findings also suggest that habilito can be a source to locally finance cattle ranching or other economic activities. Therefore, our results indicate that a network based economy may have undergone a source adaptation mechanism in addition to pursuing new economic opportunities (Cano, 2012, Cano et al., 2014).

A scenario of progressive forest loss, caused by cattle ranching or accelerated agricultural expansion is a more prominent threat to sustained Brazil nut production and in general to the resilience of the regions forestry economy. The region has until date been safeguarded from typical cattle or agro-industrial forest frontiers that have been reported from elsewhere, especially Brazil. The tenure and administrative political reforms that have partly put communities in the region on the path of change analysed here, provide safeguards against such frontier processes, because they severely limit actions of corporate actors when they are not sanctioned by communities who are now owners of land and forests. However, the region is also increasingly been exposed, because of infrastructure and land use development in neighbouring regions, in Acre, Rondonia in Brazil and Madre de Dios in Peru.

The trends observed so far have relevant implications for how community forest management in the region could be supported. Communities that had a higher per-household productivity of Brazil nut production in 1997 have experienced population growth, and subsequent increase in competition. However, this did not necessarily lead to more intensive forest use by households in all cases (Zenteno et al., 2013). Therefore, communal forest management support efforts may have a critical mediating role in legitimizing internal local rights within communities that rely on Brazil nut or other forest products. 
Our results also demonstrate that while social heterogeneity in communities has been reduced, the definition of internal local rights related to Brazil nut resources have to be adjusted, to the changes of the resident population (e.g. Cano, 2012) to avoid reaching a social threshold. However, it should also be avoided that a single Brazil nut sector plays an excessive role in defining local governance, where a possible source of thresholds may exist.

One threshold to be avoided is that local networks maintain a rigid structure, implying that local communities are more vulnerable to economic changes (Duit and Galaz, 2008). These outcomes suggest new questions as to what are the appropriate strategies to improve communal forestry activities. Do competition or financial flows from the forest drive change in major resource use? Is there a higher level of interconnectedness among communities that are far from towns, not only in social and economic condition as suggested here, but also in ecological conditions and productive levels? In our experience, such considerations are critical for promoting community forest management or tropical forest conservation.

\section{Conclusions}

Forest communities in the northern Bolivia Amazon have experienced major economic, political and social changes, throughout the region's history, and also continuously from the mid-1990s onward. Forest communities have adapted to the new economic and institutional landscape that has developed. Our quantitative analysis of these changes for the period $1997-$ 2009 showed that the most important changes included a strong increase in road access, which has improved the opportunities for interaction with the region's towns and markets. Furthermore, the incidence of informal loans (habilito) has declined, prices paid for Brazil nuts have increased, pastures for cattle ranching have augmented and the per community production of Brazil nut has grown. This situation suggests development and adaptation of the exploitation of forest resources is responsive but also presents a condition of rigidity of the exploitation system. Regional networking among productive and financial flows remains a determinant factor in the region's SES.

While forest product extraction can indeed be a source of benign forest use, our results suggest operating benign forest product economies, even when destructive logging or non-forest land use like cattle or agro-industrial production can be kept at bay, are subject to multiple forces that ultimately undermine at least one of the development and conservation objectives. Competition between households, population growth and more profitable economic opportunities are some of the forces that may threaten these benign forest product 
economies. Securing local rights will be essential and CFM promotion will need to emphasize this, especially where high population growth or improved access increase competition for resources or promote less environmental benign economic activities, which ultimately may become SES thresholds.

\section{References}

Adhikari, B. Lovett, J. C. 2006. Institutions and collective action: does heterogeneity matter in community-based resource management?. The Journal of Development Studies, 42, pp.37-41.

Agrawal, A., Chhatre, A. and Hardin, A. 2008 Changing Governance of the World's Forests, Science 320: 1460.

Andersson, K. and Ostrom, E. 2008. Analysing Decentralized Resource Regimes from a Polycentric Perspective, Political Science 41, 71-93.

Aramayo, J., 2004. La reconstrucción del sistema barraquero en el norte amazónico, análisis del decreto supremo 27572. La Paz, Bolivia, CEJIS.

Assies, W., 1997. Going Nuts for the Rain Forest: Non-timber Forest Products, Forest Conservation and Sustainabililty in Amazonia. European Review of Latin American and Caribbean Studies 62, 33-53.

Assies, W., 2002. From Rubber Estate to Simple Commodity Production: Agrarian Struggles in the Northern Bolivian Amazon. Journal of Peasant Studies 29 (3), 83-130.

Assies, W., 2006. Land Tenure Legislation in a Pluri-cultural and Multi-ethnic Society: The Case of Bolivia. Journal of Peasant Studies 33(4), 569-611.

Baland, J. M., Platteau, J. P., 1999. The ambiguous Impact of Inequality on Local Resource Management. World Development, 27(5):773-788.

Barham, B.L. andCoomes O.T., 1996. Prosperity’s Promise. The Amazon Rubber Boom and Distorted Economic Development. : Westview Press, Colorado, USA.

Benneker, C., 2008. Dealing with the State, Market and NGOs; the impact of institutions on the constitution and performance of Community Forest Enterprises (CFE) in the lowlands of Bolivia. PhD dissertation, Wageningen University, Wageningen.

Benneker, C., Bejarano, J., and Coca, M., 2005. Experiencias de Manejo Forestal Comunitario en Bolivia. CEADES-SNV, Santa Cruz, Bolivia. 
Berkes, F., Colding, J. and Folke, C. 2003. Introduction in Berkes, F., Colding, J. and Folke, C. (Eds.), Navigating Social - ecological Systems: Building Resilience for Complexity and Change. Cambridge University Press, Cambridge, pp. 1-30.

Bojanic, A., 2001. Balance is beautiful: Assessing sustainable development in the rain forests of the Bolivian Amazonia. PhD dissertation, Utrecht University, Netherlands.

Caldas, M.W., Walker, R., Arima, E. , Perz, S., Aldrich, S. and Simmons, C. 2007. Theorizing Land Cover and Land Use Change; The Peasant Economy of Amazonia Deforestation. Annals of the Association of American Geographers 97(1), 86-110. Cano, W., 2012. Formal institutions, local arrangements and conflicts in northern Bolivian communities after forest governance reforms. PhD dissertation, Utrecht University, Netherlands.

Cano,W., de Jong,W., Zuidema,P.A., Boot, R. 2014. Diverse local regulatory responses to a new forestry regime in forest communities in the Bolivian Amazon. Land Use Policy 10.1016/j.landusepol.2014.02.013.

Cespedes, M., 2005. Acceso y Distribución Interna de la Tierra en las Comunidades de Pando. CEJIS, Santa Cruz, Bolivia.

Chabay, I., Collins, K., Gutscher, H., Pfeiffer, E. , Schmidt, F. , Schreurs, M. and Siebenhüner, B. 2011. Knowledge, Learning, and Societal Change: Finding Paths to a Sustainable Future. Knowledge, Learning, and Societal Change (KLSC) project, www.klscproject.org (accessed 12.9.2013).

Christensen, L. and Krogman, N. 2012. Social Thresholds and their Translation into SocialEcological Management Practices. Ecology and Society 17(1).

Contreras-Hermosilla, A. and Vargas, M.T. 2002. Social, Environmental and Economic Dimensions of Forest Policy Reforms in Bolivia. Forest Trends, Washington, D.C.

Cronkleton, P. and Pacheco, P. 2010. Changing policy trends in the emergence of Bolivia's Brazil nut sector. In S Laird, R.J. McLain, and R.P. Wynberg (Eds), Wild Product Governance: Finding Policies That Work for Non-Timber Forest Products. Earthscan, London, pp. 5-32.

Cronkleton, P. and Albornoz, M. 2009. Acción colectiva y mercados alternativos para la castaña: Análisis comparativo de tres cooperativas en el norte amazónico de Bolivia. CIFOR, La Paz.

De Jong, W, (Ed.), 2004. Retos y perspectivas del nuevo régimen forestal en el norte amazónico boliviano. CIFOR, Bogor, Indonesia. 
De Jong, W, Cano, W., Zenteno, M. , Soriano, M., 2013. Illegal logging and Bolivia's domestic markets: The legally allowable versus the informally practicable. Forest Policy and Economics, under review.

De Jong, W., Borner, J., Pacheco, P., Pokorny, B., Sabogal, C., Benneker, C,. Cano, W., Cornejo, C., Evans, K., Ruiz, S.,Zenteno, M., 2010. Forest and adaptation to climate change: challenges and opportunities. In: Mery, G., Katila,P., Galloway, G., Alfaro, R., Kanninen, M., Lobovikov,M. and Varjo, J. (Eds), Forest and Society - Responding to global drivers of change. IUFRO World Series 25, Helsinki, pp 299-313.

Delacote, P., 2007. Agricultural Expansion, Forest Products as Safety Nets, and Deforestation, Environment and Development Economics 12, 235-249.

Duchelle, A.E., Cronkleton, P., Kainer, K.A., Guanacoma, G. , and Gezan, S., 2011.

Resource Theft in Tropical Forest Communities: Implications for Non-timber Management, Livelihoods, and Conservation. Ecology and Society 16(1), 1-4.

Duit, A. and Galaz, V. 2008. Governance and Complexity: Emerging Issues for Governance Theory. Governance 21(3), 311-335.

Frankenberger, T.K., Luther, K., Fox, K. and Mazzeo, J., 2003. Livelihood Erosion Through Time: Macro and Micro Factors that Influenced Livelihood Trends in Malawi, CARE, Southern and Western Africa Regional Management Unit.

Godoy, R.A., et al., 2007. On the Measure Of Income and the Economic Unimportance of Social Capital: Evidence from a Native Amazonian Society of Farmers and Foragers. Anthropology Research 63, 239-260.

Greenacre, M. and Pardo, R. 2006. Subset Correspondence Analysis: Visualizing

Relationships Among a Selected Set of Response Categories from a Questionnaire Survey. Fundación BBVA, Madrid.

Henkemans, A., 2001. Tranquilidad and hardship in the forest livelihoods and perceptions of Camba forest dwellers in the Northern Bolivian Amazon. PhD dissertation, Utrecht University, Netherlands.

Hinojosa, Z.E., 2005. Límites y Posibilidades para la Autogestión Forestal Indígena a la luz de la Experiencia Yuracaré. PIEB, Tinkasos 9, http://www.pieb.com.bo/tvirtual.php?id=8, (accessed 12.9.2013)

Holling, C.S., 2001. Understanding the Complexity of Economic, Ecological, and Social Systems. Ecosystems 4(5),390-405.

Homma, A.K.O., 1992. The dynamics of Extraction in Amazonia: A Historical Perspective. Advances in Economic Botany 9, 23-31. 
Homma, A.K.O. 1994. Plant extractivism in the Amazon: Limitations and Possibilities. In: Clusener-Golt, M. and Sach, I. (Eds.) Extractivism in the Brazilian Amazon: Perspectives for regional development. UNESCO, Paris.

IBCE (Bolivian Institute of Foreign Commerce), 2008. Visión económica y social de los actores de la cadena productiva de la castaña. Bolivian Institute of Foreign Commerce, La Paz.

INE (National de Statistic Institute, Bolivia), 2011. Online sectoral statistics. http://apps.ine.gob.bo/comex/Main, (accessed 12.9.2013).

INRA (National Agrarian Reform Instiute), 2011. Informe de avances gestión 2010. INRA, La Paz.

Janssen, M. A. and Scheffer, M., 2004. Overexploitation of Renewable Resources by Ancient Societies and The Role Of Sunk-Cost Effects. Ecology and Society 9(1), 6.

Labarta, R. A., White, D. S. and Scott, S. 2008. Does Charcoal Production Slow Agricultural Expansion into the Peruvian Amazon Rainforest? World Development 36(3), 527-540.

Lam, A., 2000. Tacit Knowledge, Organizational Learning and Societal Institutions: An Integrated Framework. Organization Studies 21(3), 487-513.

Liebowitz, S. J., Margolis, S. E., 2000. Path Dependence. In: Bouckaert, B. and Geest G. D. (Eds.), Encyclopedia of Law and Economics, Edward Elgar Publishing, Ghendt,Belgium, pp. 981-998).

Llanque, V. E., 2006. Forest Product Extractions, Migration and Deforestation in the Northern Bolivian Amazon. In: Leye, T.P., de Jong, W. and Abe, K. (Eds), The Social Ecology of Tropical Forests: Migration, Populations and Frontiers. Kyoto University Press and Trans Pacific Press, Kyoto and Melbourne.

March, J.G., 1991. Exploration and Exploitation in Organizational Learning. Organization Science 2,71-87.

Moore, J.W., 2011. Ecology, Capital, and the Nature of our Times, Accumulation and Crisis in the Capitalist World-Ecology. Journal of World-Systems Research 17(1),108-147.

Mwangi, E. and Ostrom, E., 2009. A Century of Institutions and Ecology in East Africa's Rangelands: Linking Institutional Robustness with the Ecological Resilience of Kenya's Maasailand. In: Beckmann, V. and Padmanabhan, M. (Eds), Springer, Utrecht, Netherlands, pp. 195-222.

Okland, R.H., 1996. Are Ordination and Constrained Ordination Alternative or Complementary Strategies in Ecological Studies? Journal of Vegetation Science 7,289-292. 
Pacheco, P., 2012. Smallholders and Communities in Timber Markets: Conditions Shaping Diverse Forms of Engagement in Tropical Latin America. Conservation and Society 10,114-23.

Pacheco, P., Barry, D., Cronkleton, P. and Larson, A. 2009. El Papel de las Instituciones Informales en el Uso de los Recursos Forestales en América Latina. CIFOR, Bogor, Indonesia.

Pacheco, P. and Cronkleton, P., 2005. El futuro del manejo forestal comunitario en el norte amazónico boliviano. CIFOR, Santa Cruz, Bolivia.

Pattanayak, S. and Sills, E.O. 2001. Do Tropical Forests Provide Natural Insurance? The Microeconomics of Non-timber Forest Product Collection in the Brazilian Amazon. Land Economics, 77(4), 595-612.

Perz, S.G. and Almeyda, A.M., 2010. A Tri-Partite Framework of Forest Dynamics: Hierarchy, Panarchy, and Heterarchy in the Study of Secondary Growth. In: Nagendra, H. and Southworth, J. (Eds), Reforesting LandscapesSprinter, Utrecht, Netherlands, pp. 59-84.

Poteete, A. Ostrom, E. 2004. Heterogeneity, Group Size and Collective Action: The Role of Institutions in Forest Management. Development and Change, 35 (3): 435-461.

Putz,F.E. Zuidema,P.A., Synnott,T. , Peña-Claros,M., Pinard, M.A., Sheil,D., Vanclay,J.K., Sist,P., Gourlet-Fleury,S., Griscom, B., Palmer,J., Zagt,R., 2012. Sustaining conservation values in selectively logged tropical forests: the attained and the attainable. Conservation Letters 0:1-8.

Renaud, F. Birkmann, G., Damm, J. , Gallopín, G. C., 2010. Understanding multiple thresholds of coupled social-ecological systems exposed to natural hazards as external shocks. Natural Hazards 55(3), 749-763.

Reyes, J. F., H. Fuentes Nay, P. Graverolle, S.B. Nakashima. 2011. Informe de estado ambiental del departamento de Pando 2009. Liga de Defensa del Medio Ambiente, LIDEMA, La Paz - Bolivia.

Ruiz, S.A., 2005. Institutional change and social conflicts over forest use in the Northern Bolivian Amazon. Freiburger Schriften zur Forst- und Umweltpolitik Band 10, Verlag Dr. Kessel, Remagen-Oberwinter, Germany.

SENASAG (National Service Animal and Food Sanitation Agency, Bolivia), 2010. Annual Records on Cattles Vaccinations for Pando Department. Cobija, Bolivia.

Sierra, R., 2001. The Role of Domestic Timber Markets in Tropical Deforestation and Forest Degradation in Ecuador: Implications for Conservation Planning and Policy. Ecological Economics 36(2), 327-340. 
Sierra, R., Rodriguez, F. and Losos, E. 1999. Forest Resource Use Change During Early Market Integration In Tropical Rain Forests: The Huaorani Of Upper Amazonia. Ecological Economics 30,107-119.

Stoian, D., 2000. Variation and Dynamics of Extractive Economies: The Rural-Urban Nexus of Non-Timber Forest Use in the Bolivian Amazon. PhD Dissertation, Freigburg University, Germany.

Stoian, D. and Henkemans, A. 2000. Between Extractivism and Peasantry: Differentiation of Rural Settlements in The Bolivian Amazon. International Tree Crop Journal 10 (4), 299319.

Takasaki, Y., Barham, B.L., Coomes, O.T., 2001. Amazonian Peasants, Rain Forest Use, and Income Generation: The Role of Wealth and Geographical Factors. Society and Natural Resources 14, 291-308.

Takasaki, Y., Coomes, O. T., Abizaid, C. and Brisson, S., 2011. Efficient Non-Market Institution with Imperfect Market : Cooperative Labour Sharing for Tropical Forest Clearing. New Haven: Yale University.

Ter Braak, C. Verdonschot, P.E., 1995. Canonical Correspondence Analysis and Related: Multivariate Methods in Aquatic Ecology. Aquatic Sciences 57 (3), 255-289.

Walker, P.A., 2005. Political Ecology: Where is the Ecology? Progress in Human Geography, $29(1), 73-82$.

Walker, B. H., Gunderson, L. H., Kinzig, A. P., Folke, C., Carpenter, S. R., Schultz, L. , 2006. A Handful of Heuristics and Some Propositions for Understanding Resilience in Social-Ecological Systems. Ecology and Society, 11(1), 13.

Zenteno, M., 2013. A Quantitative Analysis of Livelihoods in Community Forestry in the Northern Bolivian Amazon. PhD Dissertation, Utrecht University, Netherlands.

Zenteno, M., Zuidema, P.A. , de Jong, W. , Boot, R.G.A., 2013. Livelihood strategies and forest dependence: New insights from Bolivian forest communities. Forest Policy and Economics 26, 12-21.

Zuidema, P. and Boot R.G.A., 2002. Demography of the Brazil Nut Tree (Bertholletia excelsa) in the Bolivian Amazon: Impact of Seed Extraction on Recruitment and Population Dynamics. Journal of Tropical Ecology 18,1-31. 
Figure 1. The Northern Bolivian Amazon and Research Locations

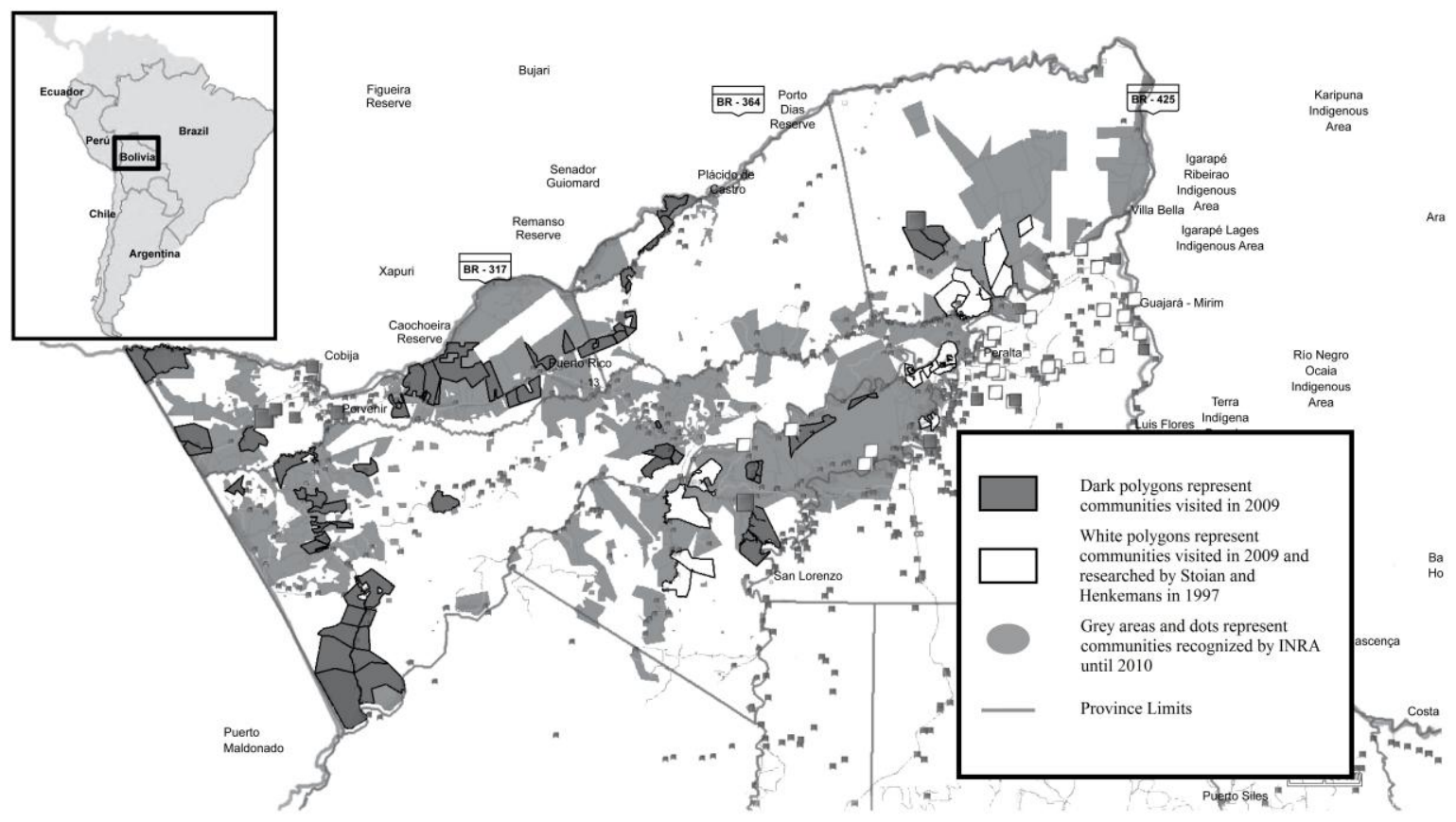


Figure 2. Correspondence Analysis of Variables of Changes in 81 Forest Communities in the Northern Bolivian Amazon

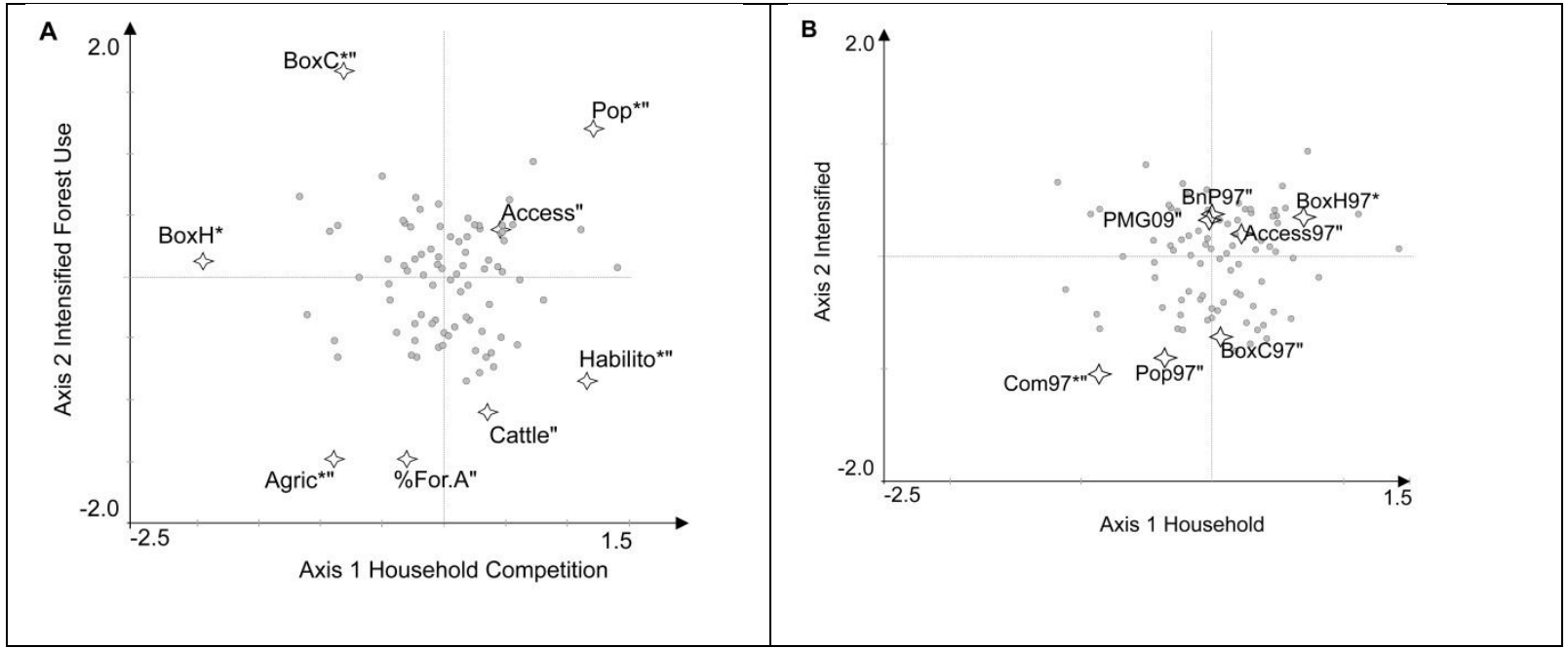

Fig 2a, axis 1 explains $25.7 \%$ of the variation across communities $(\lambda=0.047)$ and axis 2 explains $19.4 \%$ of variation $(\lambda=0.036)$; Fig $2 b$ shows results from correlating variables in 1997 and 2009 to axes in Fig 2a; dots denote communities, stars denote variables; variable codes are explained in Table 1. Dots close to each other represent communities with similar values for variables of changes. Stars close to each other represent variables with strong association. More distance from the origin represents the strength of correlation for communities and changes increasing or decreasing along the sign of the axis. Scale in both diagrams is 2 for variables (stars) and 1 for communities (dots).

* Significant correlation to horizontal axis; " significant correlation to vertical axis. 


\section{Table 1. Values and Changes for 16 Variables Quantified for 81 Forest Communities in the Northern Bolivian Amazon from 1997-2009}

$* *$ Significant $\mathrm{P}<0.01, \mathrm{NS}=$ not significant, $\mathrm{X}=$ significant for Chi-square $\mathrm{P}<0.01$. The last column contains output of paired-samples t-tests to evaluate whether differences between years were significant. For two variables (13 and 14) only data for 2009 were available. $\mathrm{C}=$ continuous variable; $\mathrm{D}=$ dicrete variable; $\mathrm{B}=$ binomial variable. ${ }^{@}$ Data from 2001 INE poll, ${ }^{* *}$ Homogeneity index (Poteete and Ostrom, 2004).

\begin{tabular}{|c|c|c|c|c|c|c|c|}
\hline \multirow[t]{2}{*}{ Name } & \multirow[t]{2}{*}{ Type } & \multirow[t]{2}{*}{ Explanation } & \multicolumn{2}{|c|}{1997} & \multicolumn{2}{|c|}{2009} & \multirow{2}{*}{$\begin{array}{l}\text { Change } \\
\quad(\Delta) \\
\mathrm{X}_{2009} / \mathrm{X}_{19} \\
\end{array}$} \\
\hline & & & Mean & St.Dev. & Mean & St.Dev. & \\
\hline Accessibility & $\mathrm{C}$ & Travel time to main town from community & 7 & 3 & 4 & 2 & $59 \%$ \\
\hline Access to market & B & $1=$ by road $0=$ by river & 0.38 & & 0.74 & & $190 \%$ \\
\hline $\begin{array}{l}\text { Household Brazil } \\
\text { nut production }\end{array}$ & $\mathrm{D}$ & $\begin{array}{l}\text { Number of Brazil nut boxes ( } 23 \mathrm{~kg} \text { of unshelled Brazil nuts) } \\
\text { sold by single household during last harvest }\end{array}$ & 178 & 157 & 142 & 103 & $80 \%$ \\
\hline $\begin{array}{l}\text { Community Brazil } \\
\text { nut production }\end{array}$ & $\mathrm{D}$ & $\begin{array}{l}\text { Number of Brazil nut boxes sold by entire community during } \\
\text { last harvest }\end{array}$ & 2821 & 3301 & 4811 & 4456 & $171 \%$ \\
\hline $\begin{array}{l}\text { Agriculture area } \\
\text { per household }\end{array}$ & $\mathrm{C}$ & Average size of agricultural plot per household & 2.16 & 1.1 & 1.01 & 0.58 & $47 \%$ \\
\hline $\begin{array}{l}\text { Cattle ranching } \\
\text { area }\end{array}$ & $\mathrm{D}$ & $\begin{array}{l}\text { Number of adult cattle heads held by community multiplied } \\
\text { by } 2 \text { ha }\end{array}$ & 167 & 276 & 256 & 454 & $153 \%$ \\
\hline aphic & & & & & & & \\
\hline Population & $\mathrm{D}$ & Inhabitants per community & 24 & 28 & 39 & 25 & $164 \%$ \\
\hline Level of education & $\mathrm{D}$ & $\begin{array}{l}\text { Number of household heads who have completed primary } \\
\text { education }\end{array}$ & 68 & 11 & 75 & 13 & $110 \%$ \\
\hline $\begin{array}{l}\text { Social } \\
\text { heterogeneity } \\
\text { index** }\end{array}$ & $\mathrm{C}$ & $\begin{array}{l}\text { Heterogeneity index } 1-\Sigma(\mathrm{xi} / \mathrm{X})^{2} ; \mathrm{x}=\text { frequency of community } \\
\text { members classified: new community members }(<3 \text { years }) \text {, not } \\
\text { born in community, not-listed in INRA archive } 2001\end{array}$ & 0.68 & 0.24 & 0.83 & 0.17 & $122 \%$ \\
\hline
\end{tabular}




\section{Economic}

10. Habilito

Informal loans

D $\%$ of the number of households that obtain informal loans;

1997 data based on community types: barraca $=100 \%$, independent community $=50 \%$

11. Econ

Economic

heterogeneity

index**

12. BnP Brazil nut price

\section{Institutional}

13. \%ForA

Percentage forest area affected*

14. $\mathrm{Ha} / \mathrm{hh}$ Forest area per household*

15. Com Legally recognised community

16. FMP

C Heterogeneity index $1-\Sigma(\mathrm{xi} / \mathrm{X})^{2}$; $\mathrm{x}$ is the frequency of community members who report in INE 2001 Poll as: agriculture, cattle ranching, extractive activities, agroforestry and services from INE poll 2001

C Local average price for a box of Brazil nut $(23 \mathrm{~kg})$ to local collector in inflation adjusted Bs/ Box

C Proportion of communal area in ha of land under land use, including savanas

C Total hectares per household locally recognized as household property

B 1= Recognized as community before 1997; 0= barraca holding

B $1=$ implemented; $0=$ not implemented management plan implemented* 
Table 2. Bivariate Pearson's Correlation between Changes of 11 Continuous Variables for the 1997- 2009 in the Northern Bolivian Amazon

\begin{tabular}{|c|c|c|c|c|c|c|c|c|c|c|}
\hline & $\begin{array}{l}\text { Box } \\
\mathrm{H}\end{array}$ & $\begin{array}{l}\text { Box } \\
\text { C }\end{array}$ & $\begin{array}{l}\text { Agri } \\
\text { c }\end{array}$ & Cattle & Pop & Educ & $\begin{array}{l}\text { Soc } \\
\mathrm{H}\end{array}$ & $\begin{array}{l}\text { Habilit } \\
\text { o }\end{array}$ & $\begin{array}{l}\text { Econ } \\
\mathrm{H}\end{array}$ & $\mathrm{BnP}$ \\
\hline Access & -0.09 & 0.06 & -0.14 & -0.14 & 0.18 & - & - & $-0.27 *$ & 0.11 & 0.11 \\
\hline BoxH & & 0.30* & $0.23^{*}$ & -0.08 & $-0.3^{* * *}$ & $\begin{array}{r}0.07 \\
- \\
0.03\end{array}$ & $\begin{array}{l}0.06 \\
-0.1\end{array}$ & $-0.21 *$ & 0.1 & 0.21 \\
\hline BoxC & & & -0.01 & -0.11 & $0.4^{* *}$ & & 0.14 & -0.16 & 0.05 & -0.02 \\
\hline Agric & & & & 0.11 & $-0.25^{*}$ & 0.04 & 0.02 & -0.04 & 0.05 & 0.19 \\
\hline Cattle & & & & & -0.19 & 0.03 & 0.12 & 0.06 & 0.03 & -0.11 \\
\hline Pop & & & & & & $\begin{array}{r}0.22 \\
*\end{array}$ & 0.15 & 0.08 & -0.14 & -0.17 \\
\hline Educ & & & & & & & $\begin{array}{r}0.25 \\
*\end{array}$ & -0.05 & 0.01 & 0.01 \\
\hline SocH & & & & & & & & -0.16 & -0.15 & -0.06 \\
\hline Habilito & & & & & & & & & -0.01 & -0.14 \\
\hline EconH & & & & & & & & & & 0.01 \\
\hline
\end{tabular}

Data shown as correlation coefficients. Variable codes are explained in Table 1. In bold indicates signicant correlations. " Significance at $\mathrm{P}<0.05 .{ }^{* *}$ Significance at $\mathrm{P}<0.01$. 
Table 3. Correlations between the Two Canonical Axes for 16 Variables Describing Changes of 81 Forest Communities in the Northern Bolivian Amazon

\begin{tabular}{|c|c|c|c|c|}
\hline & \multicolumn{2}{|c|}{ Changes } & \multicolumn{2}{|c|}{ Variables in $1997 / 2001$} \\
\hline & Axis 1 & Axis 2 & Axis 1 & Axis 2 \\
\hline Access & 0.09 & $0.30 * *$ & 0.19 & $0.28 * *$ \\
\hline $\operatorname{Road}^{\mathrm{a}}$ & & & 0.13 & .03 \\
\hline BoxH & $-0.87 * *$ & 0.09 & $0.35 * *$ & 0.20 \\
\hline BoxC & $-0.44 * *$ & $0.67 * *$ & 0.03 & $-0.52 * *$ \\
\hline Agric & $-0.49 * *$ & $-0.52 * *$ & 0.10 & 0.20 \\
\hline Cattle $^{\mathrm{s}}$ & 0.01 & $-0.27 * *$ & 0.04 & -0.10 \\
\hline Pop & $0.44 * *$ & $0.59 * *$ & -0.20 & $-0.39 * *$ \\
\hline Educ & -0.04 & -0.16 & -0.10 & 0.02 \\
\hline SocH & 0.08 & -0.16 & 0.14 & 0.20 \\
\hline Habilito & $0.43 * *$ & $-0.33 * *$ & 0.09 & 0.10 \\
\hline EconH & -0.05 & 0.14 & -0.14 & 0.04 \\
\hline $\mathrm{BnP}$ & -0.17 & -0.14 & 0.15 & $0.26 * *$ \\
\hline$\%$ For. $^{\mathrm{s}}$ & -0.16 & $-0.38 * *$ & & \\
\hline $\mathrm{Ha} / \mathrm{HH}^{\mathrm{s}}$ & -0.05 & 0.00 & & \\
\hline Community $^{\mathrm{a}}$ & & & $-0.26 *$ & $-0.35 * *$ \\
\hline FMP $^{\mathrm{a}}$ & 0.09 & $0.20 *$ & & \\
\hline
\end{tabular}

Pearson correlation was performed for continuous and discrete variables, but not for binary variables. ${ }^{*}$ Significance at $\mathrm{P}<0.05 ;{ }^{* *}$ significance at $\mathrm{P}<0.01 ;{ }^{\mathrm{a}} \mathrm{T}$ independence test as performed. ${ }^{S}=$ static data from 2009 was used in the correlations. Variable codes are explained in Table 1

Table 3. Values and Changes for 16 Variables Quantified for 81 Forest Communities in the Northern Bolivian Amazon from 1997-2009

** = Significant $\mathrm{P}<0.01, \mathrm{NS}=$ not significant, $\mathrm{X}=$ significant for Chi-square $\mathrm{P}<0.01$. The last column contains output of paired-samples t-tests to evaluate whether differences between years were significant. For two variables (13 and 14) only data for 2009 were available. $C=$ continuous variable; $\mathrm{D}=$ dicrete variable; $\mathrm{B}=$ binomial variable. ${ }^{@}$ Data from $2001 \mathrm{INE}$ poll, Homogeneity index (Poteete and Ostrom, 2004). 


\begin{tabular}{|c|c|c|c|c|c|c|c|}
\hline \multirow[t]{2}{*}{ Name } & \multirow[t]{2}{*}{ Type } & \multirow[t]{2}{*}{ Explanation } & \multicolumn{2}{|c|}{1997} & \multicolumn{2}{|c|}{2009} & \multirow{2}{*}{$\begin{array}{l}\text { Change } \\
(\Delta) \\
\mathrm{X}_{2009} / \mathrm{X}_{19}\end{array}$} \\
\hline & & & Mean & St.Dev. & Mean & St.Dev. & \\
\hline Accessibility & $\mathrm{C}$ & Travel time to main town from community & 7 & 3 & 4 & 2 & $59 \%$ \\
\hline Access to market & $\mathrm{B}$ & $1=$ by road; $0=$ by river & 0.38 & & 0.74 & & $190 \%$ \\
\hline $\begin{array}{l}\text { Household Brazil } \\
\text { nut production }\end{array}$ & $\mathrm{D}$ & $\begin{array}{l}\text { Number of Brazil nut boxes ( } 23 \mathrm{~kg} \text { of unshelled Brazil nuts) } \\
\text { sold by single household during last harvest }\end{array}$ & 178 & 157 & 142 & 103 & $80 \%$ \\
\hline $\begin{array}{l}\text { Community Brazil } \\
\text { nut production }\end{array}$ & $\mathrm{D}$ & $\begin{array}{l}\text { Number of Brazil nut boxes sold by entire community during } \\
\text { last harvest }\end{array}$ & 2821 & 3301 & 4811 & 4456 & $171 \%$ \\
\hline $\begin{array}{l}\text { Agriculture area } \\
\text { per household }\end{array}$ & $\mathrm{C}$ & Average size of agricultural plot per household & 2.16 & 1.1 & 1.01 & 0.58 & $47 \%$ \\
\hline $\begin{array}{l}\text { Cattle ranching } \\
\text { area }\end{array}$ & $\mathrm{D}$ & $\begin{array}{l}\text { Number of adult cattle heads held by community multiplied } \\
\text { by } 2 \text { ha }\end{array}$ & 167 & 276 & 256 & 454 & $153 \%$ \\
\hline aphic & & & & & & & \\
\hline Population & $\mathrm{D}$ & Inhabitants per community & 24 & 28 & 39 & 25 & $164 \%$ \\
\hline Level of education & $\mathrm{D}$ & $\begin{array}{l}\text { Number of household heads who have completed primary } \\
\text { education }\end{array}$ & 68 & 11 & 75 & 13 & $110 \%$ \\
\hline $\begin{array}{l}\text { Social } \\
\text { heterogeneity } \\
\text { index** }\end{array}$ & $\mathrm{C}$ & $\begin{array}{l}\text { Heterogeneity index } 1-\Sigma(\mathrm{xi} / \mathrm{X})^{2} ; \mathrm{x}=\text { frequency of community } \\
\text { members classified: new community members }(<3 \text { years }) \text {, not } \\
\text { born in community, not-listed in INRA archive } 2001\end{array}$ & 0.68 & 0.24 & 0.83 & 0.17 & $122 \%$ \\
\hline
\end{tabular}

\section{Economic}

26. Habilito Informal loans

27. Econ

Economic

heterogeneity

index**

28. BnP Brazil nut price

\section{Institutional}

29. \%ForA

30. $\mathrm{Ha} / \mathrm{hh}$

31. Com

32. FMP
Percentage forest area affected* Forest area per household* Legally recognised community Forest management plan implemented*
D $\%$ of the number of households that obtain informal loans; 1997 data based on community types: barraca $=100 \%$, independent community $=50 \%$

C Heterogeneity index $1-\Sigma(\mathrm{xi} / \mathrm{X})^{2}$; $\mathrm{x}$ is the frequency of community members who report in INE 2001 Poll as: agriculture, cattle ranching, extractive activities, agroforestry and services from INE poll 2001

C Local average price for a box of Brazil nut $(23 \mathrm{~kg})$ to local
$(\Delta)$

$9 \%$

$90 \%$

$0 \%$

$71 \%$

$47 \%$

$53 \%$ collector in inflation adjusted Bs/ Box

C Proportion of communal area in ha of land under land use, including savanas

C Total hectares per household locally recognized as household property

B 1= Recognized as community before 1997; 0= barraca holding

B $\quad 1=$ implemented; $0=$ not implemented 
Table 4. Bivariate Pearson's Correlation between Changes of 11 Continuous Variables for the 1997- 2009 in the Northern Bolivian Amazon

\begin{tabular}{|c|c|c|c|c|c|c|c|c|c|c|}
\hline & $\begin{array}{l}\text { Box } \\
\mathrm{H}\end{array}$ & $\begin{array}{l}\text { Box } \\
\text { C }\end{array}$ & $\begin{array}{l}\text { Agri } \\
\text { c }\end{array}$ & Cattle & Pop & Educ & $\begin{array}{l}\text { Soc } \\
\mathrm{H}\end{array}$ & $\begin{array}{l}\text { Habilit } \\
\text { o }\end{array}$ & $\begin{array}{l}\text { Econ } \\
\mathrm{H}\end{array}$ & $\mathrm{BnP}$ \\
\hline Access & -0.09 & 0.06 & -0.14 & -0.14 & 0.18 & - & - & $-0.27 *$ & 0.11 & 0.11 \\
\hline BoxH & & 0.30* & $0.23^{*}$ & -0.08 & $-0.3^{* * *}$ & $\begin{array}{r}0.07 \\
- \\
0.03\end{array}$ & $\begin{array}{l}0.06 \\
-0.1\end{array}$ & $-0.21 *$ & 0.1 & 0.21 \\
\hline BoxC & & & -0.01 & -0.11 & $0.4^{* *}$ & & 0.14 & -0.16 & 0.05 & -0.02 \\
\hline Agric & & & & 0.11 & $-0.25^{*}$ & 0.04 & 0.02 & -0.04 & 0.05 & 0.19 \\
\hline Cattle & & & & & -0.19 & 0.03 & 0.12 & 0.06 & 0.03 & -0.11 \\
\hline Pop & & & & & & $\begin{array}{r}0.22 \\
*\end{array}$ & 0.15 & 0.08 & -0.14 & -0.17 \\
\hline Educ & & & & & & & $\begin{array}{r}0.25 \\
*\end{array}$ & -0.05 & 0.01 & 0.01 \\
\hline SocH & & & & & & & & -0.16 & -0.15 & -0.06 \\
\hline Habilito & & & & & & & & & -0.01 & -0.14 \\
\hline EconH & & & & & & & & & & 0.01 \\
\hline
\end{tabular}

Data shown as correlation coefficients. Variable codes are explained in Table 1. In bold indicates signicant correlations. ${ }^{*}$ Significance at $\mathrm{P}<0.05 .{ }^{* *}$ Significance at $\mathrm{P}<0.01$. 
Table 3. Correlations between the Two Canonical Axes for 16 Variables Describing Changes of 81 Forest Communities in the Northern Bolivian Amazon

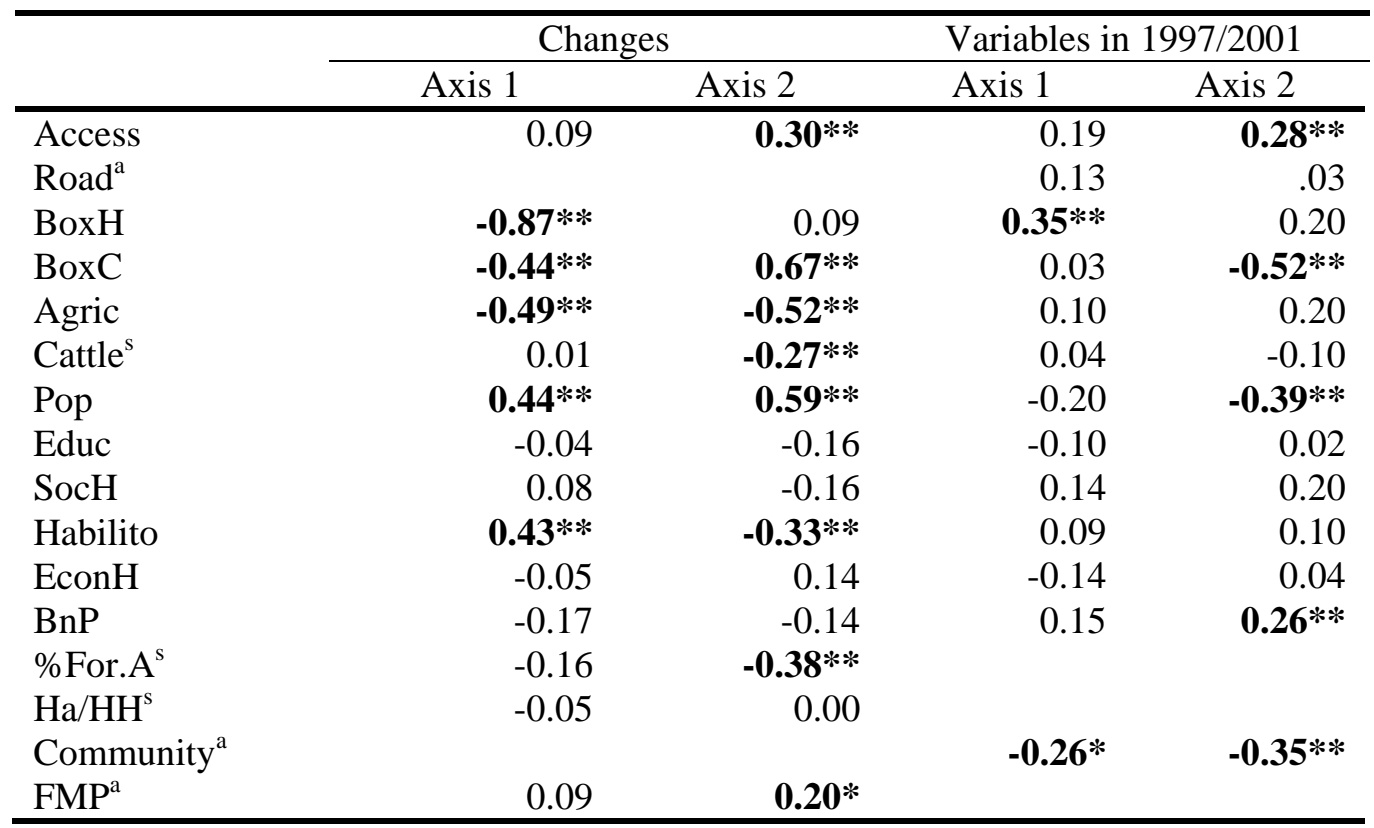

Pearson correlation was performed for continuous and discrete variables, but not for binary variables. ${ }^{*}$ Significance at $\mathrm{P}<0.05 ;{ }^{* *}$ significance at $\mathrm{P}<0.01 ;{ }^{\mathrm{a}} \mathrm{T}$ independence test as performed. ${ }^{\mathrm{S}}=$ static data from 2009 was used in the correlations. Variable codes are explained in Table 1 